\title{
Factorial design applied to sodium activation of a Brazilian bentonite
}

\author{
(Planejamento fatorial aplicado a ativação sódica de \\ uma bentonita brasileira)

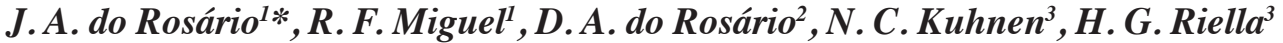 \\ ${ }^{1}$ Universidade do Estado de Santa Catarina, CAV, Laboratório de Tecnologias Limpas, Lages, SC, Brazil \\ ${ }^{2}$ Universidade do Sul de Santa Catarina, EEL, Laboratório de Certificação, Palhoça, SC, Brazil \\ ${ }^{3}$ Universidade Federal de Santa Catarina, EQA, Laboratório de Materiais e Corrosão, Florianópolis, SC, Brazil
}

\begin{abstract}
Sodium bentonites are extensively used in industry because they have specific properties that are wanted for several purposes, such as high swelling, thixotropy, and cation exchange capacity. Otherwise, calcium and polycationic bentonites, which are predominant in Brazil, need to be chemically treated by sodium activation to expand their content of interlayer exchangeable sodium cations, which increases these properties. The present study shows the factorial design of the sodium activation for a polycationic bentonite from Quatro Barras, Paraná. The factors considered in the study were: reagent $\left(\mathrm{NaOH}\right.$ and $\left.\mathrm{Na}_{2} \mathrm{CO}_{3}\right)$, concentration $(1 \%$ and $5 \%)$ and contact time ( 24 and $72 \mathrm{~h}$ ). The response variables were swelling and cation exchange capacity. Statistical analysis indicated significant effects of all factors over swelling and response surface methodology indicated optimal activation with sodium carbonate at $5 \%$ for $24 \mathrm{~h}$.
\end{abstract}

Keywords: sodium activation, swelling, cation exchange capacity, factorial design.

Resumo

Bentonitas sódicas são muito utilizadas na indústria por possuírem propriedades específicas desejáveis para diferentes finalidades, como inchamento, tixotropia, e capacidade de troca catiônica elevados. Por outro lado, bentonitas cálcicas e policatiônicas, predominantes no Brasil, necessitam de beneficiamento químico através da ativação sódica para o aumento de seu teor de íons de sódio interplanares trocáveis, o que leva a maximização destas propriedades. Este estudo apresenta o delineamento experimental do processo de ativação sódica de uma bentonita policatiônica de Quatro Barras, Paraná. Os fatores utilizados no estudo foram: reagente ( $\mathrm{NaOH}$ e $\mathrm{Na}_{2} \mathrm{CO}_{3}$ ), concentração (1\% e 5\%) e tempo de contato $(24$ e $72 \mathrm{~h}$ ). O inchamento de Foster e a capacidade de troca cationnica foram utilizados como variáveis resposta no delineamento. A análise estatística indicou efeitos significativos dos fatores sobre o inchamento e a metodologia de superfície de resposta indicou uma ativação ótima com o carbonato de sódio a $5 \%$ por $24 \mathrm{~h}$.

Palavras-chave: ativação sódica, inchamento, capacidade de troca catiônica, planejamento fatorial.

\section{INTRODUCTION}

Sodium bentonites are clays of great commercial value due to their use in different applications, such as drilling fluids, ligands on casting molds, precursor material of organophilic clays, adsorbents, among others. Such uses are provided by their high swelling, cation exchange, thixotropy, and adsorption capacities. Those properties are directly related to a greater presence of sodium cations in the interlayer space of bentonites, which characterizes them as sodium bentonites [1-3]. Brazil possesses reserves of calcium and polycationic bentonite, but does not have natural sources of sodium bentonite [4]. In order to use national sources, avoiding an expensive dependence of imported sodium bentonites, local industries usually improve their sodium content through sodium activation.

* (D) https://orcid.org/0000-0002-7159-581X
The salt more commonly used for this treatment is sodium carbonate, but no study was performed in order to compare it with other reagents and to obtain the best parameters of activation.

Factorial design and surface response methodology (SRM) are important tools in the treatments of clays, enabling optimization of processes through the reduction of costs, reagent consumption and duration, and maximizing the performance and quality of products [5]. Statistical analysis also allows a better understanding of the real influences over the process variables and conditions, resulting on more reliable results. Few studies involving the chemical treatment of bentonite clays were supported by statistical analysis and/or SRM: the optimization of soda-activation on bentonites for foundry sand [6] and acid activation of bentonite for adsorption [7] are examples. Most of the studies approach the optimization of the treatments parameters with bentonite-based materials, 
for chemical oxygen demand (COD) removal [8], for the removal of dyes [9], and bleaching capacity on cotton oil [10], among others. This paper purposes a factorial design to achieve the best response for reagent, concentration and time of activation over the properties of swelling and cation exchange capacity, with the objective to optimize the process of sodium activation on bentonites.

\section{MATERIALS AND METHODS}

Materials: clay samples from Quatro Barras, Paraná, were used as bentonite source. This region has the largest Brazilian bentonite reserve (estimated as $45.6 \%$ of the total) and it is the least commercial exploited, accounting for only $4.6 \%$ of raw bentonite produced in Brazil [11].

Bentonite pre-treatment and characterization: aqueous suspensions of $100 \mathrm{~g} / \mathrm{L}$ from the raw clays were prepared and subjected to high-speed agitation, followed by wet classification with a 350 mesh sieve, in order to diminish the content of impurities, such as carbonates and free silica. Later, the raw and pre-treated samples were characterized by: 1) X-ray diffraction (XRD), using the powder method with $\mathrm{CuK \alpha}(\lambda=1.5418 \AA)$ as incident radiation, operating at $40 \mathrm{kV}$ and $30 \mathrm{~mA}$, with a step size of $0.02^{\circ}$, for the identification of the present mineralogical phases (especially the clay minerals and impurities), which was done by comparison with files from the Inorganic Crystal Structure Database (ICSD); and 2) scanning electron microscopy (SEM), at operating voltage of 10 to $15 \mathrm{kV}$, to evaluate the microstructure and surface profile of the powdered samples, which were previously covered with a gold microfilm to provide conductivity.

Factorial design: to evaluate the best condition of sodium activation, a $2^{3}$ factorial design was applied. The factors and levels (codified and real) of the design are presented in Table I. The tests were performed in duplicate, with a total of 16 experiments performed randomly [12, 13]. Statistical analyses of data were developed with the software Statistica 6.0 and JMP 14.1. Analysis of variance (ANOVA) was carried out for significance evaluation of the factors over the responses of treatment. The F-test was used to compare means, and the percentage of explained variation was calculated by:

$$
\% \text { of explained variation }=\frac{\mathrm{QS}_{\text {effect }}}{\mathrm{QS}_{\text {total }}}
$$

Table I - Levels of the independent variables (factors). [Tabela I - Níveis das variáveis independentes (fatores).]

\begin{tabular}{ccc}
\hline \multirow{2}{*}{ Factor } & \multicolumn{2}{c}{ Level } \\
& -1 & +1 \\
\hline Reagent & $\mathrm{NaOH}$ & $\mathrm{Na}_{2} \mathrm{CO}_{3}$ \\
Concentration (\%) & 1 & 5 \\
Contact time (h) & 24 & 72 \\
\hline
\end{tabular}

Activation process: for all tests, clay suspensions of $100 \mathrm{~g} / \mathrm{L}$ were prepared from pre-treated samples and kept stirring for $1 \mathrm{~h}$ for deagglomeration. After that, reagent solutions at the determined concentration were added and left at a constant stirring (at around $1000 \mathrm{rpm}$ ) for the determined time. Later, the samples were washed and dried in an oven at $60{ }^{\circ} \mathrm{C}$. The samples were then crushed in a ball mill and sieved at 200 mesh to obtain particles of a maximum diameter of $75 \mu \mathrm{m}$.

Evaluation of the sodium activation: the activation process was evaluated according to the influence over the properties of swelling and cation exchange capacity (CEC). The swelling index was determined according to Foster's method, which consisted of the slow disposal of $1 \mathrm{~g}$ of bentonite sample into a beaker filled with $100 \mathrm{~mL}$ of distilled water. After $24 \mathrm{~h}$ of total rest, the increase in the dispersion volume was observed. Sodium bentonites can achieve swelling indexes superior to $20 \mathrm{~mL} / \mathrm{g}$, while calcium bentonites do not show any significant swelling. Cation exchange capacity was obtained through the method of methylene blue adsorption, in accordance with ASTM C 837-84 standard [14]. This method calculates CEC from the volume of methylene blue added to the clay dispersion until the visual achievement of saturation point (marked by the formation of a halo of constant diameter around a drop taken from the mixture).

\section{RESULTS AND DISCUSSION}

Bentonite characterization: the mineralogical pattern of the natural clay is shown in Fig. 1, revealing the presence of montmorillonite, $\mathrm{Na}_{0.3} \mathrm{Al}_{2}(\mathrm{Si}, \mathrm{Al})_{4} \mathrm{O}_{10}(\mathrm{OH})_{2} \cdot 2 \mathrm{H}_{2} \mathrm{O}$, with a (001) interlayer spacing of $15.63 \AA\left(5.65^{\circ} 2 \theta\right)$, and significant amounts of quartz and kaolinite, with minor quantities of albite and orthoclase. This result showed that the clay from Quatro Barras is highly heterogeneous, so the pre-treatments are mandatory in order to reduce the content of non-clay minerals that negatively interfere on the bentonite properties. The SEM images in Fig. 2 show the surface morphology of the bentonite before and after

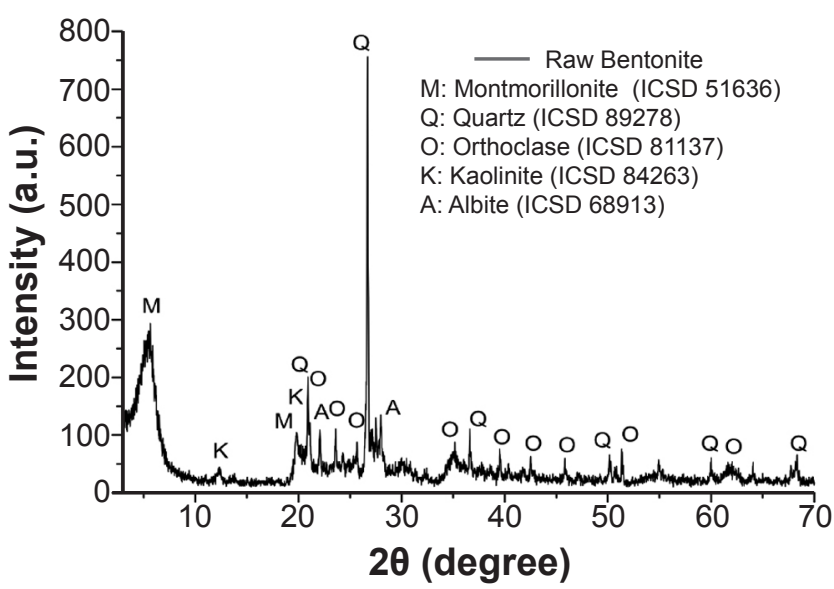

Figure 1: XRD pattern of natural clay.

[Figura 1: Padrão de DRX da argila natural.] 


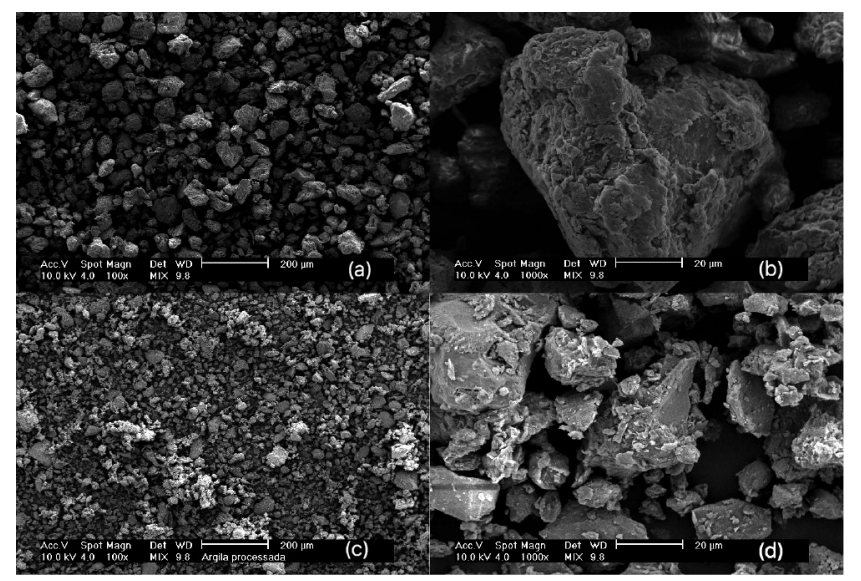

Figure 2: SEM micrographs of: a,b) natural clay; and c,d) pretreated clay.

[Figura 2: Micrografias de MEV de: a,b) argila natural; e c,d) argila pré-tratada.]

the pre-treatment, at different magnifications. The raw clay presented large particles in blocks, which was consistent with the presence of accessory minerals, that acted as ligands in the formation of agglomerates. After pre-treatment, the surface had a more fragmented shape, with more channels, contact areas, and smaller particles, which is more favorable for ion exchange. Thus, the pre-treated samples were chosen as precursors for sodium activation.

Factorial design: Table II shows the results of the factorial design for swelling and CEC. The two reagents presented different responses related to their concentration: the best performance with $\mathrm{NaOH}$ was at the lowest concentration $(1 \%)$ and the highest time $(72 \mathrm{~h})$. The inverse was obtained with $\mathrm{Na}_{2} \mathrm{CO}_{3}$, which presented better values at the highest concentration (5\%) and the lowest time $(24 \mathrm{~h})$. The concentration and contact time are therefore conditioned to the activation reagent. The data was first analyzed by ANOVA tests, with a confidence level of $95 \%$. Analyzing the statistical results for swelling on Table III, the F-test showed that the studied factors responded for $99.96 \%$ of the variation observed on swelling and that, except for the interaction between reagent and contact time, all other variables had a significant effect over the swelling. The statistical results showed also that the model was fitted for prediction, with a strong linear correlation. The Pareto graph (Fig. 3) showed that the concentration $\left(x_{2}\right)$ and the interaction between concentration and time $\left(\mathrm{x}_{2} \cdot \mathrm{x}_{3}\right)$ were the factors that most influenced the property of swelling. The statistical results for CEC (Table IV), on the other hand, showed that p-value was below significance level, what indicated that there were no statistic differences between groups, so all considered variables did not have a significant effect over CEC. However, the explained variation is notably high, and the sum and medium squares due to regression were very superior to those from other sources of variation. This confirmed that the experimental results were satisfactory at a confidence level of $95 \%$ and that a derived mathematical model can be used for optimization of the sodium activation process. The Eqs. B and C represent, respectively, the coded mathematical models for swelling and CEC; parameters inside brackets do not show statistical significance. The models showed that swelling was highly influenced by the factors considered, which could not be observed for cation exchange capacity. Therefore, the choice of reagent, concentration and contact time interfere only on the expansibility of the clay in water.

$$
\begin{aligned}
& \hat{\mathrm{y}}_{\mathrm{Sw}}=9.68+0.812 \mathrm{x}_{1}-1.81 \mathrm{x}_{2}-0.812 \mathrm{x}_{3}+ \\
& 1.06 \mathrm{x}_{1} \mathrm{x}_{2}-0.687 \mathrm{x}_{1} \mathrm{x}_{3}-1.81 \mathrm{x}_{2} \mathrm{x}_{3}
\end{aligned}
$$

Table II - Results of the factorial design.

[Tabela II - Resultados do planejamento fatorial.]

\begin{tabular}{cccccc}
\hline Test & $\mathrm{x}_{1}$ & $\mathrm{x}_{2}$ & $\mathrm{x}_{3}$ & $\begin{array}{c}\text { Swelling } \\
(\mathrm{mL} / \mathrm{g})\end{array}$ & $\begin{array}{c}\text { CEC } \\
(\mathrm{meq} / 100 \mathrm{~g})\end{array}$ \\
\hline 1 & -1 & -1 & -1 & 10.0 & 95.0 \\
2 & -1 & -1 & +1 & $\mathbf{1 3 . 5}$ & $\mathbf{9 0 . 0}$ \\
3 & -1 & +1 & -1 & 8.0 & 85.0 \\
4 & -1 & +1 & +1 & 4.0 & 57.5 \\
5 & +1 & -1 & -1 & 11.0 & 87.5 \\
6 & +1 & -1 & +1 & 11.5 & 82.5 \\
7 & +1 & +1 & -1 & $\mathbf{1 3 . 0}$ & $\mathbf{1 0 0 . 0}$ \\
8 & +1 & +1 & +1 & 6.5 & 65.0 \\
\hline$x_{1}$-reagent; $x_{2}$ - concentration; $x_{3}$-contact time.
\end{tabular}

Table III - Results of ANOVA for swelling.

\begin{tabular}{|c|c|c|c|c|}
\hline $\begin{array}{l}\text { Source of } \\
\text { variation }\end{array}$ & QS & df & QM & F ratio $p$-value \\
\hline Model & 75.94 & 6 & 12.66 & \multirow{4}{*}{$405.000 .0308^{*}$} \\
\hline Error & 0.03125 & 1 & 0.0313 & \\
\hline Total & 75.97 & 7 & & \\
\hline $\begin{array}{c}\text { Explained } \\
\text { variation (\%) }\end{array}$ & \multicolumn{2}{|l|}{99.96} & & \\
\hline Source $^{\#}$ & QS & $\mathrm{df}$ & p-value & \\
\hline$x_{1}$ (reagent) & 5.281 & 1 & $0.0489 *$ & \\
\hline $\mathrm{x}_{2}$ (concentration) & 26.28 & 1 & $0.0219 *$ & \\
\hline $\mathrm{x}_{3}($ contact time $)$ & 5.281 & 1 & $0.0489 *$ & \\
\hline $\mathrm{x}_{1} \cdot \mathrm{x}_{2}$ & 9.031 & 1 & $0.0372 *$ & \\
\hline $\mathrm{x}_{1} \cdot \mathrm{x}_{3}$ & 3.781 & 1 & 0.0577 & \\
\hline $\mathrm{x}_{2} \cdot \mathrm{x}_{3}$ & 26.28 & 1 & $0.0219 *$ & \\
\hline
\end{tabular}

[Tabela III - Resultados da ANOVA para o inchamento.]

$\alpha=0.05 ; R^{2}=0.999589 ; *$ - shows statistical significance; ${ }^{*}$ - as a function of the independen variables.

Term
X2 (concentration)
X1 (concentration) ${ }^{*}$ X3 (contact time)
X1 (reagent) ${ }^{*}$ X2 (concentration)
X1 (reagent)
X3 (contact time)
X1 (reagent) ${ }^{*}$ X3 (contact time)

Estimate

Figure 3: Pareto graph for swelling.

[Figura 3: Gráfico de Pareto para o inchamento.] 
Table IV - Results of ANOVA for CEC.

[Tabela IV - Resultados da ANOVA para o CTC.]

\begin{tabular}{|c|c|c|c|c|c|}
\hline $\begin{array}{l}\text { Source of } \\
\text { variation }\end{array}$ & QS & $\mathrm{df}$ & QM & F ratio & p-value \\
\hline Model & 1473.44 & 6 & 245.57 & \multirow{4}{*}{34.93} & \multirow{4}{*}{0.1288} \\
\hline Error & 7.0313 & 1 & 7.031 & & \\
\hline Total & 1480.47 & 7 & & & \\
\hline $\begin{array}{c}\text { Explained } \\
\text { variation }(\%)\end{array}$ & \multicolumn{2}{|l|}{99.52} & & & \\
\hline Source $^{\#}$ & $\mathrm{QS}$ & $\mathrm{df}$ & $\mathrm{p}$-value & & \\
\hline $\mathrm{x}_{1}$ (reagent) & 7.031 & 1 & 0.5000 & & \\
\hline $\mathrm{x}_{2}$ (concentration) & 282.0 & 1 & 0.0997 & & \\
\hline $\mathrm{x}_{3}($ contact time $)$ & 657.0 & 1 & 0.0656 & & \\
\hline $\mathrm{x}_{1} \cdot \mathrm{x}_{2}$ & 175.8 & 1 & 0.1257 & & \\
\hline $\mathrm{x}_{1} \cdot \mathrm{x}_{3}$ & 7.031 & 1 & 0.5000 & & \\
\hline $\mathrm{x}_{2} \cdot \mathrm{x}_{3}$ & 344.5 & 1 & 0.0903 & & \\
\hline
\end{tabular}
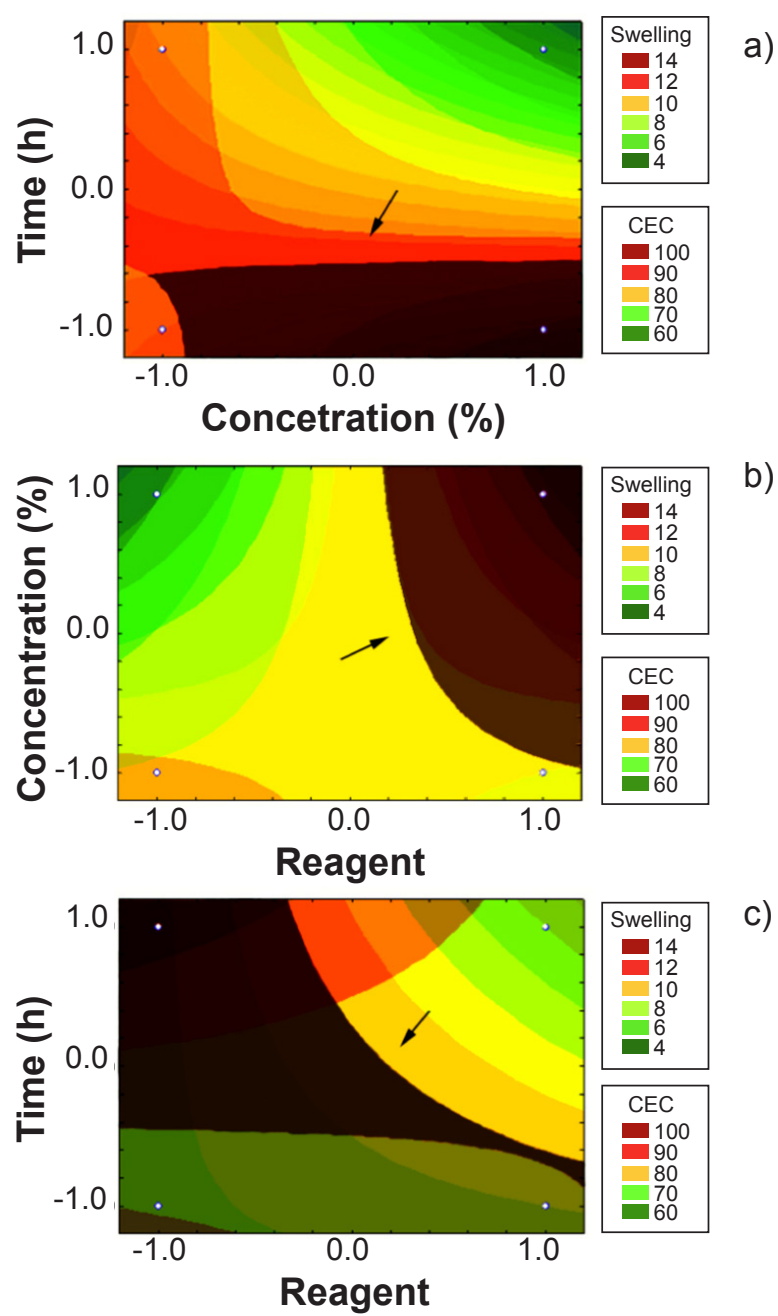

c)

Figure 4: Overlayed contour plots for: a) reagent $\mathrm{Na}_{2} \mathrm{CO}_{3}(+1)$; b) contact time of $24 \mathrm{~h} \mathrm{(-1)}$; and c) concentration of $5 \%(+1)$.

[Figura 4: Gráficos de curvas de níveis sobrepostos para: a) reagente $\mathrm{Na}_{2} \mathrm{CO}_{3}(+1)$; b) tempo de contato de $24 \mathrm{~h}(-1)$; e c) concentração de $5 \%(+1)$.]

$$
\begin{aligned}
& \hat{\mathrm{y}}_{\mathrm{CEC}}=82.8-0.937\left\langle\mathrm{x}_{1}\right\rangle-5.937\left\langle\mathrm{x}_{2}\right\rangle-9.062\left\langle\mathrm{x}_{3}\right\rangle+ \\
& 4.687\left\langle\mathrm{x}_{1} \mathrm{x}_{2}\right\rangle-0.937\left\langle\mathrm{x}_{1} \mathrm{x}_{3}\right\rangle-6.562\left\langle\mathrm{x}_{2} \mathrm{x}_{3}\right\rangle
\end{aligned}
$$

Optimization of the activation process: the optimum values were obtained by the surface response method (Fig. 4). The stronger interactions occurred between the variables of concentration and time, which was evidenced by a curvier surface. In order to estimate the optimal levels, the graphs of the same scale were overlaid and, as a result, the most shaded areas (indicated by an arrow in the graphs) corresponded to the combination of parameters that reached the highest values for the desired properties (swelling and CEC). After considering the intervals that coexisted in the three plots, and decoding the respective levels, the optimum parameters were defined as: reagent $=\mathrm{Na}_{2} \mathrm{CO}_{3}$; salt concentration $=5 \%$; time $=24 \mathrm{~h}$. Despite presenting an inferior performance, the levels for $\mathrm{NaOH}$ that achieved the best results were at $1 \%$ and $72 \mathrm{~h}$.

Both solutions presented similar $\mathrm{pH}$ during activation (Fig. 5), so the differences between each reagent could be explained by the effect of $\mathrm{OH}^{-}$on the structure of montmorillonites. At higher concentrations, the significant amount of hydroxide ions led to the dissolution of the primary silicate from clay minerals, as showed on previous studies $[15,16]$. On the other hand, another study showed that montmorillonites subjected to alkaline environments based on carbonate ions first display a predominance on the cation exchanges, before the dissolution of silicates and aluminates from the clay structure [17]. This also explains why a reduced time of activation $(24 \mathrm{~h})$ for the treatment with $\mathrm{Na}_{2} \mathrm{CO}_{3}$ resulted in better performance; at longer periods of agitation, the disruption of the clay mineral begins to take place, overlapping the cation exchange process.

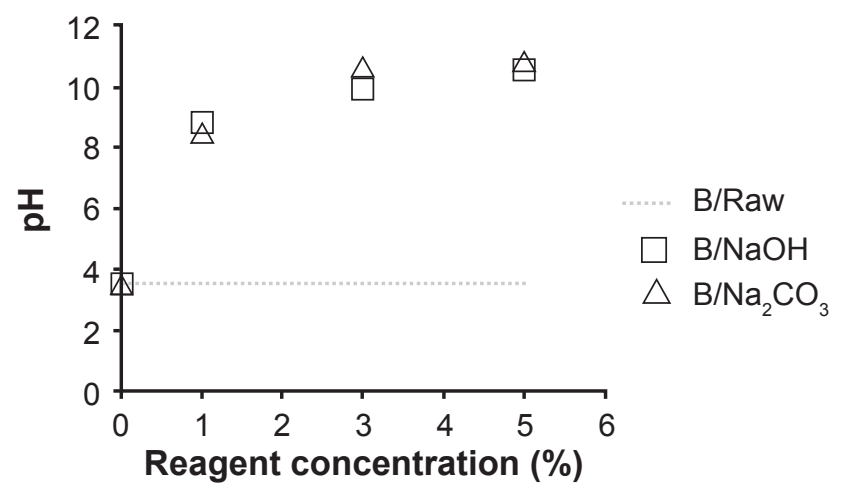

Figure 5: $\mathrm{pH}$ variation during sodium activation. [Figura 5: Variação de pH na ativação sódica.]

\section{CONCLUSIONS}

The $\mathrm{F}$ ratios and the explained variations for both parameters showed that the proposed models were well fitted. Obtained models and statistics indicated that the considered factors (reagent, concentration, and contact time) influenced swelling. The effects on CEC did not show 
statistical significance. Concentration and time presented the most expressive interaction between variables. Response surface methodology could be applied for optimization and resulted in the use of $\mathrm{Na}_{2} \mathrm{CO}_{3}$ at $5 \%$ for $24 \mathrm{~h}$ as the best levels for sodium activation. The $\mathrm{pH}$ variation during activation was the same for both reagents, so the differences between treatments were due to the effect of the anionic species from the reagents over the predominance of dissolution or cation exchange on montmorillonite.

\section{REFERENCES}

[1] M.S. Hassan, N.A. Abdel-Khalek, Appl. Clay Sci. 13 (1998) 99.

[2] M.C.P. Machado, J.T. Langbehn, C.M. Oliveira, F. Elyseu, M. Cargnin, T.E.A. Frizon, M. Peterson, Cerâmica 64, 370 (2018) 207.

[3] I.A. Silva, F.K.A. Sousa, R.R. Menezes, H.S. Ferreira, G.A. Neves, H.C. Ferreira, Cerâmica 64, 369 (2018) 109.

[4] A.B. Luz, F.A.F. Lins, "Rochas e minerais industriais", CETEM/MCT, Rio Janeiro (2005) 217.

[5] A.J.A. Gama, J.M.R. Figueirêdo, A.L.F. Brito, M.A. Gama, G.A. Neves, H.C. Ferreira, Cerâmica 64, 369 (2018) 57.

[6] F. Boylu, Appl. Clay Sci. 52 (2011) 104.
[7] L. Rožić, T. Novaković, S. Petrović, Appl. Clay Sci. 48 (2010) 154.

[8] M. Ligaray, C.M. Futalan, M.D. de Luna, M.W. Wan, J. Clean. Prod. 175 (2018) 145.

[9] A.A. Oladipo, M. Gazi, J. Water Process Eng. 2 (2014) 43.

[10] E.G. Kirali, O. Laçin, J. Food Eng. 75 (2006) 137.

[11] K.A. Medeiros, in "Sumário mineral 2015", DNPM, Brasília (2016) 135.

[12] B. Barros Neto, I.S. Scarminio, R.E. Bruns, Planejamento e otimização de experimentos, Ed. Unicamp, S. Paulo (1996).

[13] G.E.P. Box, W.G. Hunter, J.S. Hunter, Statistics for experiments - an introduction to design, data analysis and model building, John Wiley Sons, New York (1978).

[14] ASTM C837-09, "Standard test method for methylene blue index of clay", ASTM (2015).

[15] M. Rozalen, F.J. Huertas, P.V. Brady, Geochim. Cosmochim. Acta 73 (2009) 3752.

[16] D. Savage, K. Bateman, P. Hill, C. Hughes, A. Milodowski, J. Pearce, E. Rae, C. Rochelle, Appl. Clay Sci. 7 (1992) 33.

[17] H. Hayashi, M. Yamada, Clays Clay Miner. 38 (1990) 308.

(Rec. 19/07/2018, Rev. 18/10/2018, Ac. 06/11/2018) 